
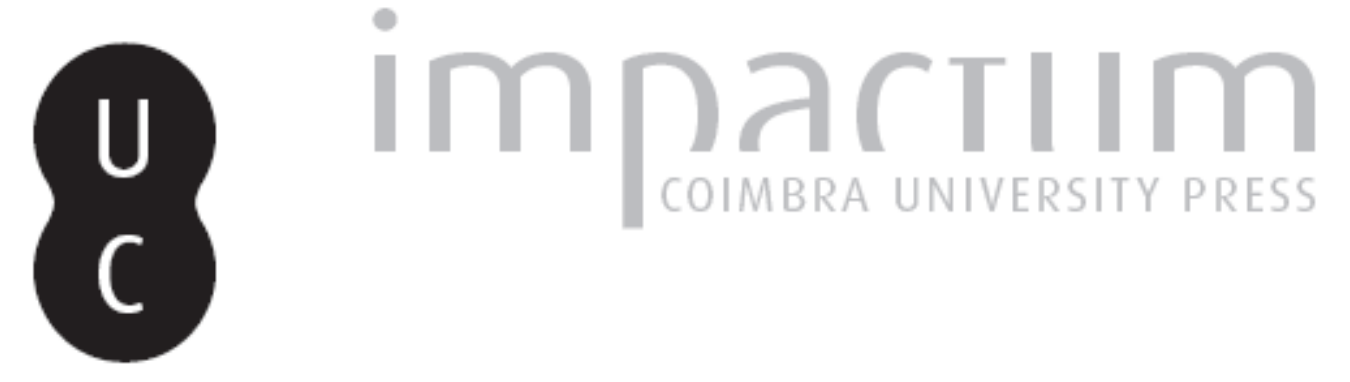

\title{
The Visigothic society and its cemeteries
}

\section{Autor(es): Leitão, Francisco}

Publicado por: Centro de História da Sociedade e da Cultura

URL persistente:

URI:http://hdl.handle.net/10316.2/39422

DOI:

DOI:http://dx.doi.org/10.14195/1645-2259_12_1

Accessed : $\quad$ 26-Apr-2023 15:28:41

A navegação consulta e descarregamento dos títulos inseridos nas Bibliotecas Digitais UC Digitalis, UC Pombalina e UC Impactum, pressupõem a aceitação plena e sem reservas dos Termos e Condições de Uso destas Bibliotecas Digitais, disponíveis em https://digitalis.uc.pt/pt-pt/termos.

Conforme exposto nos referidos Termos e Condições de Uso, o descarregamento de títulos de acesso restrito requer uma licença válida de autorização devendo o utilizador aceder ao(s) documento(s) a partir de um endereço de IP da instituição detentora da supramencionada licença.

Ao utilizador é apenas permitido o descarregamento para uso pessoal, pelo que o emprego do(s) título(s) descarregado(s) para outro fim, designadamente comercial, carece de autorização do respetivo autor ou editor da obra.

Na medida em que todas as obras da UC Digitalis se encontram protegidas pelo Código do Direito de Autor e Direitos Conexos e demais legislação aplicável, toda a cópia, parcial ou total, deste documento, nos casos em que é legalmente admitida, deverá conter ou fazer-se acompanhar por este aviso.

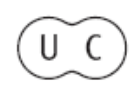


evista de História da Sociedade e da Cultura

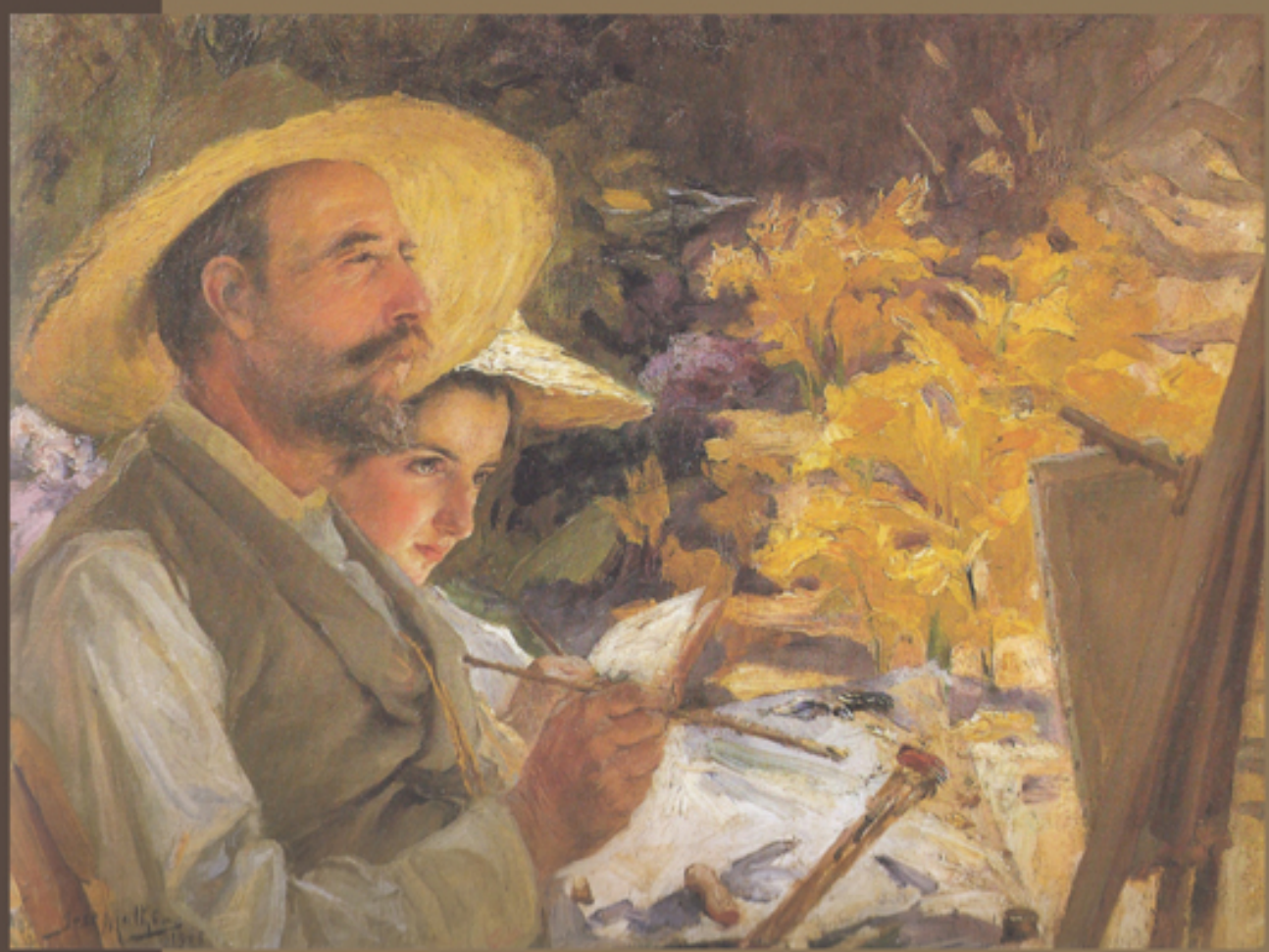

Centro de História da Sociedade e da Cultura Universidade de Coimbra 


\title{
The Visigothic society and its Cemeteries
}

\author{
Francisco Leitão \\ University of Strasbourg \\ francisco.leitao@gmail.com \\ Texto recebido em /Text submitted on: 10/01/2012 \\ Texto aprovado em /Text approved on: 24/04/2012
}

\section{Resumo/Abstract:}

Os vestígios arqueológicos deixados pelos Visigodos em forma de cemitérios podem ser importantes fontes para a compreensão da sociedade que viveu durante a Alta Idade Média na Península Ibérica. O principal objectivo deste trabalho é compreender que tipo de conclusões, se algumas, podem ser inferidas através deste tipo de fonte.

Uma primeira ideia propondo que o espaço destinado aos mortos reflecte a sociedade dos vivos não seria nova e uma segunda, defendendo a próxima relação entre os dois, ainda que menos óbvia continuaria a ser relativamente consensual. Originando da necessidade prática de lidar com os corpos dos elementos defuntos, as sociedades humanas tiveram e têm que encontrar respostas e procedimentos que irão, inevitavelmente, reflectir as suas ansiedades, crenças e esperanças.

A Alta Idade Média Peninsular não poderia ser diferente. Não é claro, contudo, se é possível compreender tais atitudes culturais meramente a partir das pequenas informações disponíveis pois este foi um período de grande instabilidade e de profundas contradições, onde diferentes povos e culturas experimentaram um complexo processo de contacto e influencia mútuos.

Sabemos de antemão que, devido a tal heterogeneidade e ao limitado número de fontes disponíveis, não será possível alcançar sólidas conclusões acerca das mentalidades do tempo. Este trabalho, contudo, tentará perceber se, a partir destes vestígios arqueológicos, algumas ideias podem ser desenvolvidas sobre a Identidade e o Poder na sociedade em questão.

The archeological evidence left by the Visigothic cemeteries can prove to be a significant piece of information for a better analysis of the society that lived in Early Medieval Hispania. The main purpose of this essay is precisely to understand what kind of conclusions, if any, can be extracted from them.

A first idea stating that the places of the dead reflect the society of the living is not a new one but a second, sustaining that the habitats of the living and the places of the dead were always in a close relation might be less obvious even if fairly consensual ${ }^{1}$. Springing from a very practical need of dealing with the dead bodies, human societies had and have to find answers and procedures which will, inevitably, reflect their anxieties, beliefs and hopes.

Early Medieval Hispania could not be any different. However, it is unclear if we can understand those cultural attitudes from the little evidence at our disposition for this was a

* RIPOLL, Gisela; "The arrival of the Visigoths in Hispania: Population problems and the process of acculturation", in W. POHL y H. REIMITZ (ed.), Strategies of Distinction. The Construction of Ethnic Communities, 300-800. Leiden: European Science Foundation - J. Brill, 1998, p. 267. 
period of great instability and striking contradictions, where different peoples and cultures were in a complex process of mutual contact and influence.

One knows from the start that, due to this great complexity and to the scarcity of sources available, it will not be possible to reach solid conclusions about the mentalities of the time. This essay, however, will attempt to understand if, from the archeological evidence left by the cemeteries, ideas can be developed about Identity and Power in the Visigothic society

Palavras chave/Keywords:

Alta Idade Média; Visigodos; Cemitérios; Etnias; Identidade.

Early Midde Ages; Visigoths; Cemeteries; Ethnicity; Identity. 


\section{The Visigothic occupation of the Iberian Peninsula}

The Goths crossed the whole European Continent before reaching its western confines. This long voyage in space and time brought irreversible implications to the Roman Empire, but also to the barbarian peoples themselves. The first Goths to cross the Pyrenees were far different from their ancestors who had left Scandinavia. Language, religion, law, culture were all in a permanent and dramatic evolution and this dynamic, coupled with the complex mosaic of barbarian groups of the time, makes it very hard to determine what exactly a Visigoth was' ${ }^{1}$.

The inhabitants of the Peninsula had also experienced an important and deep contact with the barbarian tribes since the previous arrival of Alans, Sueves and Vandals. When the Visigoths arrived in Hispania both invaders and invaded were not completely unknown or hostile to each other. Indeed, an important part of the Roman elites had facilitated the process of occupation of the previous barbarians because they longed for a stabilized power, a vacancy that Rome was no longer capable of fulfilling².

The precise details of the circumstances that saw the Visigoths stepping into the Peninsula are object of debate and the sources are either insufficient or unclear. Indeed, they are even contradictory and different documents point, for example, both 28 September and 12 October 409 as the moment when, thanks to an act of deliberate treachery from the Roman units, the Pyrenees were opened to the barbarians ${ }^{3}$.

The nature of the Visigothic presence for the V century is a subject of debate and the depth of the earliest occupation remains unclear. Some authors classified it as mere "military exercises"4 while others argued that, from that early time, the Visigothic kingdom established in Toulouse ruled the region by gradually replacing the degraded Roman institutions and had a capacity

${ }^{1}$ COLLINS, Roger; Visigothic Spain, 409-711. Oxford: Blackwell Pub., 2004, p. 17.

2 COLLINS, 2004, p. 13.

3 COLLINS, 2004, p. 11-13.

4 WOLFRAM, H.; Die Goten - Von den Anfängen bis zur Mitte des sechsten Jahrhunderts. Entwurf einer historischen Ethnographie, Munich (4. ed.): 2001, p. 196. 
to actually influence and even determine happenings to the point where Hispania could be considered as part of their domains in the V century 5 .

There is less controversy about the following century when, after being defeated by the Frankish in 507, a significant part of the Visigoths finally left Southern Gaul to enter the Peninsula. Once again, though, due to the disputes about the degree of assimilation of the Visigothic and Roman populations in Aquitaine, it is arguable whether the majority of the Goths crossed the Pyrenees or not ${ }^{6}$.

Demographically, we can only rely on vague figures to determine the number of Visigoths who did the journey and almost each historian presents his own figures ${ }^{7}$. According to Gisela Ripoll, whose calculations derive precisely from the number and size of the necropolises, they would be around 100,000 entering an area where between 9 and 12 million people were living 8 .

These days, the difference in numbers might not be surprising anymore but they are still striking and even more so if we note that the superiority of the Roman population was, more than just statistical, also cultural ${ }^{9}$. On the other hand, the political role played by the newcomers provoked a complex relation of mutual influence. The contrasts between the several peoples in the Peninsula softened during Liuvigild's reign (568-586) when the Visigoths defeated the remaining barbarians, causing their disappearance or assimilation, and massively reduced the byzantine presence ${ }^{10}$.

These are, however, mostly political events and the social acculturation is much harder to date. It must have reached a maturation point under the same king for it was him who abolished the decree that forbade marriage between people of different origins. By his own admission, these marriages were

5 KOCH, Manuel; "Gotthi intra Hispanias sedes acceperunt. Consideraciones sobre la supuesta inmigración visigoda en la Península Ibérica” in PYRENAE, núm. 37, vol. 2: 2006, p. 97.

$6 \mathrm{KOCH}, 2006$, p. 84.

7 RIPOLL, Gisela; "Características generales del poblamiento y la arqueología funeraria visigoda de Hispania" in Espacio, Tiempo y Forma, I, 2. Madrid: 1989, p. 393.

8 RIPOLL, Gisela; La ocupación visigoda en época romana a través de sus necrópolis (Hispania), Collecció de Tesis Microfitxades, Servei de Publicacions de la Universitat de Barcelona, Barcelona, 1991, p. 13.

9 HILlGARTH, J. N.; The Visigoths in history and legend. Toronto: Pontifical Institute of Mediaeval Studies: 2009, p. 10.

${ }^{10}$ COLLINS, 2004, p. 26-37. 
already taking place and the abolition must have been more of a declaration of intent towards the unification of the kingdom than a real social shift ${ }^{11}$. The social melting would therefore be dated sometime around the first half of the VI century.

A final point in the unification of the Peninsula was the III Council of Toledo, held in 589, where the king Reccared occupied an analog position to the one played by Constantine in Nicaea, and which marked the renunciation by the barbarians to Arianism and their final conversion to Catholicism. The shift, together with the definitions of the rites and the civil law later adopted, the closest to the Roman canons in the barbarian world ${ }^{12}$, allowed a complete mixture of the peoples living in the Peninsula.

Isolated from the devastation and confusion reigning in Italy and France in the VI and VII centuries, and in spite of some internal instability, the merging peoples were able to build a political structure and a proper identity to an extent that, when the Arabs arrived, no visible distinctions could be made between old Romans or Visigoths ${ }^{13}$. The focus of this essay is that moment of transition and the process of acculturation itself.

\section{The so-called Visigothic Cemeteries}

The Visigothic presence in Hispania lasted for almost three centuries and would control the whole Peninsula. The evidence left is often scarce and, inevitably, unevenly distributed in time and space. Burial evidence, in particular, is available for several stages of the occupation and often brings us very different information relating to each moment of Visigothic Hispania. Because of its length, in both time and space, the Goth kingdom presents very different realities and, unsurprisingly, the sources confirm that

${ }^{11}$ ORLANDIS, José; Historia de España. Época Visigoda (409-711). Madrid: Editorial Gredos, 1987, p. 100-102.

${ }^{12}$ HILLGARTH, 2009, p. 14.

${ }^{13}$ HILLGARTH, 2009, p. 18-19. 
V century Baetica was a very different reality than Gallaecia at the time of the Muslim conquest ${ }^{14}$.

This essay is mainly based on a specific type of cemeteries, excavated in the geographical centre of the Iberian Peninsula, between the rivers Tagus and Douro. They belong to people who inhabited those lands at the time of the early Visigothic presence, on the turn from the V to the VI century. These populations of free barbarians were dedicated to rural economy and elected the Meseta as a starting point for economic and strategic reasons ${ }^{15}$. The written sources do not testify to such settlement but, considering their scarcity, silence cannot be taken as conclusive. ${ }^{16}$

The cemeteries have been deeply studied in the last years and the studies made by Gisela Ripoll Lopez will be followed here to characterize them, in particular, by her PhD thesis, defended in 1991, of which some interpretations are now surpassed by works of the same author but where the main description of the archeological evidence remains up to date.

These necropolises can be framed within what Joachim Werner termed the Reihengraberfelder, the civilization of the lined cemeteries, which is characteristic of many parts of Europe for the Early Medieval period and was strictly linked with the Germanic peoples ${ }^{17}$. The distinction was usually made through the orientation of the graves, all parallel, towards West, and the placement of goods inside them. Both feature in the Iberian burials, with the single difference being that no weapons are found in male graves and the clothing ${ }^{18}$ in mostly feminine ${ }^{19}$. Finally, the space is organized in regular groups of graves, leaving spaces of open land between them ${ }^{20}$.

${ }^{14}$ RIPOLL, Gisela; "Symbolic Life and Signs of Identity in Visigothic Times", in P. HEATHER (ed.), The Visigoths from the migration period to the seventh century: an ethnographic perspective. Woodbridge, Suffolk: Center for Interdisciplinary Research on Social Stress, 1999, p. 406.

${ }^{15}$ RIPOLL, 1991, p. 19; RIPOLL, 1998, p. 278.

${ }^{16} \mathrm{KOCH}, 2006$, p. 86.

${ }^{17}$ WERNER, Joaquim; “Zur Entstehung der Reihengraberzivilisation” in Archaeologica Geographica 1: 1950, p. 23-32.

${ }^{18}$ Clothing is here taking in a broad sense and often the materials found are objects of personal adornment such as buckles or brooches.

${ }^{19}$ HALSALL, Guy; Cemeteries and Society in Merovingian Gaul. Selected studies in History and Archeology, 1992-2009. Leiden: 2010, p. 93; RIPOLL, 1999, p. 410.

${ }^{20}$ RIPOLL, 1998, p. 279. 
The cemeteries could have as many as 300 graves and probably held most of the initial Visigothic people. We can assume that necropolises had some sort of signalization that allowed different generations to recognize them and keep burying their dead members there but, unlike in other European places, there is very little evidence for this in the Hispanic case ${ }^{21}$.

A further problem for this study is to relate each cemetery with a village because we often know the location of one but do not know where the other was. We do know that, as a general rule, they follow the Merovingian features and were located between $500 \mathrm{~m}$ and $10,000 \mathrm{~m}$ from the settlements, in hidden places ${ }^{22}$.

A meaningful characteristic is the fact that, in spite of the differences in their age, the sepulchers containing Visigothic and Roman materials occupy the same places, without any distinction of groups or sectors, specifically allocated to each ethnicity ${ }^{23}$. Thus, the only element allowing us to link some graves with the barbarians are the objects, whose nature seems to point, with relative certainty, to their Goth origin or influence ${ }^{24}$.

All the necropolises were simultaneously abandoned and their closing has been indicated as a moment when both communities would be deeply merged and the habits brought by the Visigoths finally completely dissolved.

Natural differences can be detected between burials in this area and other cemeteries in the Peninsula, such as Baetica, which was more romanized, where the Visigoths did not settle immediately and no substantial differences can be traced from the Roman period ${ }^{25}$.

${ }^{21}$ RIPOLL, 1991, p. 35-41.

${ }^{22}$ RIPOLL, 1991, p. 30.

${ }^{23}$ RIPOLL, 1998, p. 279.

${ }^{24}$ RIPOLL, 1999, p. 406-414; KOCH, 2006, p. 86; HEATHER, Peter; The Goths, Oxford: Blackwell Publishers, 1998, p. 202.

${ }^{25}$ RIPOLL, 1991, p. 20. 


\title{
An identitarian perspective
}

\author{
"a man or woman with a Lombard-style brooch \\ is no more necessarily a Lombard than \\ a family in Bradford with a Toyota is Japanese"26
}

The Visigothic necropolises were first called as such in the forties by German scholars, who, in that very specific context, claimed to have found the Goth national clothing in the traces of the cemeteries ${ }^{27}$. The differences verified in the style of cemeteries, when compared to the previous period, still support the idea that something changed in this period but, in the last decades, historians have stressed the continuities from the Roman world into the newly established barbarian kingdoms and raised questions about the possibility of such a strict relation between the ethnicity of a certain group and the objects or tools found in archeological excavations. The inevitable consequence for the study of Iberian cemeteries is the question of whether the Visigothic cemeteries should be considered as such.

The first and main reason for an immediate negative answer to the question is the absolute lack of comparable evidence for the presence of the Visigoths in Southern Francia. If the objects really express the Gothic national clothing, there would have to be some similar evidence in the places crossed by them. However, there is a complete silence in the Narbonenesis lands for the whole period spent there by the barbarian people ${ }^{28}$.

Alternatively, some scholars have proposed links between the objects and other peoples. Peter Heather suggested that the artifacts could have been used by the Romans, instead ${ }^{29}$. There is not, however, any good reason to justify the fact that the Roman population would be following a Goth fashion that was not even shared by the Visigoths. A second possibility was argued

${ }^{26}$ WICKHAM, Chris; Early Medieval Italy: central power and local society, 400-1000: University of Michigan Press: 1989, p. 68.

${ }^{27}$ RIPOLL, Gisela; "Las necrópolis visigodas. Reflexiones en torno al problema de la identificación del asentamiento visigodo en Occidente según los materiales arqueológicos", in Hispania Gothorum. San Ildefonso y el reino visigodo de Toledo, Catálogo de la Exposición, Museo de Santa Cruz de Toledo, Toledo: 2007, p. 65.

${ }^{28}$ HEATHER, 1998, p. 203; RIPOLL, 2007, p. 63-64.

${ }^{29}$ HEATHER, 1998, p. 203. 
by Patrick Périn, stating that this habit would be a consequence of a group of Ostrogoths, who, after joining the Visigothic column somewhere on its journey, revived the Gothic traditions within them ${ }^{30}$. This is a complex reading of the available evidence and the whole participation of that Ostrogoth group is not supported by any source ${ }^{31}$.

The impossibility of a close linking between the archeological evidence and some perfectly defined ethnic group is, by itself, telling. It indicates that the mingling between invaders and invaded might have happened sooner than is usually indicated and even at this early stage of the Visigothic presence, differences between groups would be lighter and harder to perceive than the old schemes wanted to believe.

The early dating of the cemeteries and the economic characteristics of the lands make plausible for an early settlement of Visigoths in this area. It follows a pattern testified to in other parts of Europe where a peaceful arrangement was made, so that two thirds of the land left by the collapsed highest Roman aristocracy would be given to the newcomers while the remaining third would be retained by the local Romans ${ }^{32}$.

That would explain the Gothic objects and open the possibility of a society where both groups lived, if not mixed, in some pacific coexistence, which, inexorably led to its final mingling. Recently, micro-studies have been made in some villages of central Iberia and the idea of very distinct groups, living within them, seems to make little sense ${ }^{33}$.

The social, cultural and religious reality of the period was a direct consequence of transformations which shaped new and different elites. As they developed, they reproduced different models of identity, Roman in some aspects and Gothic in others ${ }^{34}$.

${ }^{30}$ PÉRIN, Patrick; "L'armée de Vidimer et la question des depôts funéraires chez les Wisigoths en Gaule et en Espagne." In L'armée romaine et les barbares du IIIe au VIIe siècle. Paris: Association Française d'Archéologie Mérovingienne y Musée des Antiquités Nationales, 1993, p. 411-423.

${ }^{31}$ RIPOLL, 2007, p. 65-66.

${ }^{32}$ HILGARTH, 2009, p. 6-7.

${ }^{33}$ RIPOLL, 2007, p. 67-68.

${ }^{34}$ RIPOLL, 2007, p. 70. 


\section{Power and the cemeteries}

Up to this moment, the Visigothic cemeteries have not often been used as evidence to characterize power in Early Medieval Hispania. A reason for this is probably the fact that they do not offer an object for much distinction in comparison to other regions of the same period. Indeed, almost all conclusions that can be sketched from them would not be too different from the ones drawn elsewhere in Europe.

Cemeteries, medieval or modern, are an element of power through several dimensions which can, schematically, be divided into two groups: power over the place itself and power over rituals performed there ${ }^{35}$.

As was usual in Europe, the Visigothic cemeteries were most often located outside the walls, contrasting with the later medieval cemeteries, placed within the cities ${ }^{36}$. The I Council of Braga declares very clearly the procedure to be followed and, despite some exceptions, in most cases it was respected. The rules would soon change, though, with the rise of the phenomena of the martyrs, who were to be buried inside the cities, a procedure that became more and more frequent in Iberia and Europe ${ }^{37}$.

Most Early Medieval cemeteries were literately placed in dead ends, most often not very far, but still hidden, from main roads ${ }^{38}$. This represents an important shift from Roman times, when great mausoleums were built alongside main roads in a demonstration of a will to show and celebrate the power of the dead ${ }^{39}$.

The later distant burials often expressed a desire to live far from the dead, an attitude springing from the fear of the deceased, and in other regions of Europe some bodies were even found decapitated ${ }^{40}$. The rise of the burials of martyrs inside cities represented a new shift, with the living wanting to

${ }^{35}$ HARKE, Heinrich; "Cemeteries as places of power." in Topographies of power in the Early Middle Ages (The Transformation of the Roman World, 6). De Jong, M. and Theuws, F. with van Rhijn, C. (eds.). Brill, Leiden, Boston and Cologne: 2001, p. 19-28.

${ }^{36}$ RIPOLL, 1991, p. 17.

${ }^{37}$ RIPOLL, 1991, p. 31-32; RIPOLL, 1998, p. 267.

${ }^{38}$ RIPOLL, 1991, p. 30-31.

${ }^{39}$ HARKE, 2001, p. 15-17.

${ }^{40}$ HARKE, 2001, p. 21-23. 
be close to the old martyrs, the place they thought to be the best to assure them salvation.

Ownership of the cemeteries is also an obvious element of power for, those who held them could decide over the people to be buried there, the conditions or procedures of the burial and could even be entitled to the donation of offerings ${ }^{41}$. Because they were located outside the villages and the same cemetery was used by different communities, the necropolises of the Meseta are unlikely to have had any private owner.

An even harder task is to study the rituals related to funerals. It is certain that more or less precise actions had to be performed when the body was carried to be buried and there had to be some ceremony marking the act. However, very little evidence is available to support hypotheses of how this might have happened.

Burial rituals have been used elsewhere in Europe to study several aspects of the populations: size, gender relations or attitudes towards young and old people, for example ${ }^{42}$. Because of the scarcity of evidence, such analysis is, at this point, hard to do for the Iberian cemeteries.

The sources available indicate certain procedures but they sometimes contradict one another. The Council of Elvira forbids, for example, fires in cemeteries ${ }^{43}$ and some years later, the Council of Braga also states that masses were not to be held in cemeteries, but the III Council of Toledo exhorts the singing of psalms while forbidding funerary sermons ${ }^{44}$. Contrasting with the Merovingian case, there are no traces of food or any other sort of animals and vegetables being used. However, the need for the II Council of Braga to forbid it in 572 suggests that it was probably done at some point ${ }^{45}$.

The same Council determined how to bury criminals by stating that they ought to be placed in communal spaces but despite the appearance of graves containing more than one body, it is impossible to determine whether

\footnotetext{
${ }^{41}$ HARKE, 2001, p. 15.

${ }^{42}$ HALSALL, Guy; Early medieval cemeteries: an introduction to burial archeology in the post-Roman West. Glasgow: Cruithne Press, 1995, p. 65-68.

${ }^{43}$ RIPOLL, 1991, p. 75.

${ }^{44}$ RIPOLL, 1991, p. 76-77.

${ }^{45}$ RIPOLL, 1991, p. 77.
} 
these belonged to criminals or not. The disposition of the graves shows spaces between them which could be adequate to perform rituals but it is even harder to be sure about that ${ }^{46}$. Archaeology also points to traces on the ground, suggesting some sort of fire or the burning of something related to the ritual of burying ${ }^{47}$.

Finally, the objects found in the Visigothic necropolises provide information that matches the behaviour of other Early Medieval peoples as there was no food in the graves, but several tools and instruments were found in them. The placement of goods in sepulchers was a distinctive mark of the period and has been an important source for its understanding because it can shed light on several characteristics of medieval societies ${ }^{48}$. The practice of burying goods itself appears in opposition with the above mentioned construction of mausoleums and churches in the Roman and Later Medieval Age ${ }^{49}$.

Halsall, Harke and Childe relate this evolution, contemporary to the collapse of the Roman Empire, as a symptom of a rising social instability where elites were not consolidated, but instead, fighting for their status ${ }^{50}$. Pader, when dealing with an analogous phenomenon in Anglo-Saxon cemeteries reaches similar conclusions as Halsall, who studied Merovingian Gaul: both reject that the placement of goods had any origin in religious or ethnic factors but, instead, it was linked with the maintenance of the status of the family who was burying its dead member ${ }^{51}$. According to Halsall, these ceremonies could be attended by large groups and, therefore, its grammar had to be vastly understood ${ }^{52}$.

Extending these remarks to the Hispanic case, Ripoll points out that the Visigothic sepulchers seem to be organized, not according to religion or

${ }^{46}$ RIPOLL, 1991, p. 45.

${ }^{47}$ RIPOLL, 1991, p. 75.

${ }^{48}$ HALSALL, 1995, p. 65-68.

${ }^{49}$ HARKE, 2001, p. 15-17.

${ }^{50}$ HALSALL, 1995, p. 66; HARKE, 2001, p. 24-25.

${ }^{51}$ HALSALL, Guy; La Civitas Mérovingienne de Metz. BLAFAM 12: 1988 p. 50-52; PADER, E. J.; "Material symbolism and social relations in mortuary behaviour" in Anglo-Saxon Cemeteries. P. A. Rahtz, T. M. Dickinson \& L. Watts. Oxford: 1980, p. 143-159.

${ }^{52}$ HALSALL, 1995, p. 67. 
richness but, instead, by familiar proximity ${ }^{53}$. It can also be verified that the highest percentage of graves with goods belongs to the very unstable $\mathrm{V}$ century, when about $40 \%$ of the sepulchers had some sort of goods in them, and, in the following century, objects can be found in no more than $10 \%$ of the cases ${ }^{54}$. Like the building of mausoleums, the placement of goods in graves in the Meseta and in Europe, is a social statement, where through the burial of the lost member, the living family intends to impose its status.

Halsall also points out that this theory would explain the silence coming from Southern France. In a strongly Romanized region, where the elites were more stable, the need for these demonstrations of power would not be felt, which avoided the rise of the burials mentioned above. The smoother transition of power from Roman times to the Middle Ages would have, as a consequence, an equally smooth evolution of the cemeteries in Aquitaine ${ }^{55}$.

The difference expressed by the two kinds of stage used for the spectacle of power might be a consequence of the horizon of time in which the elites affirmed their position. Both in Roman times as in the later Middle Ages, when the elites were strongly grounded, there would be a long term perspective of power, testified to by the imposing, solid and lasting constructions. The placement of objects is, on the other hand, a one-off act, where only the people present at the last moment witness the statement. This relation cannot be applied from a mechanist approach as, surely, reality was much more complex but the argument seems to find support in the sources ${ }^{56}$.

Be that as it may, it shows that despite its scarcity and ambiguity, some conclusions can be drawn from archeological evidence of old cemeteries. Those places were, in the words of Harke, an "arena for the display of the power of the living" 57 , social constructions reflecting the correlation of powers that existed in the Visigothic and Early Medieval societies.

\footnotetext{
${ }^{53}$ RIPOLL, 1998, p. 279.

${ }^{54}$ RIPOLL, 1989, p. 416-417.

${ }^{55}$ HALSALL, 2010, p. 106.

${ }^{56}$ HARKE, 2001, p. 29-30.

${ }^{57}$ HARKE, 2001, p. 31.
} 


\section{Final Remarks}

The first conclusion to be drawn from the previous observations is that cemeteries do provide material suitable to be used for the understanding of the Visigothic society. Despite all the difficulties surrounding the analysis, precious information is given by this type of source and, at times, its use is the only available path.

Human societies are complex organizations in permanent evolution and any given age is suitable to be labeled as a time of changes and contradictions in tension. The label is, however, unavoidable when referring to Early Modern Hispania and it should be taken in all its depth.

Most aspects of the Visigothic world are forums for open debate and the nature of the available sources is such that they often raise more questions than answers. Any attempt to sketch ideas about it must have those constraints has a background.

The available evidence indicates that the occupation of the Peninsula was probably made earlier than usually thought, with the Visigoths gaining an important position even before their defeat of 507 that forced the subsequent massive migration. This extends the period of contact between the two populations and argues for an earlier process of acculturation. The Frankish victory would force them to define the Peninsula as their only domain but it would not be the sole reason responsible for their presence.

Moreover, that acculturation was surely more complex and deeper than some studies previously wanted to believe. The difficulties in differentiating a Visigothic from a Roman grave, even at an early stage, suggest that ethnic distinctions were never self-evident. Both peoples had been under mutual influence for a long time, to a level at which the difference between them became vague and dubious.

Burial evidence, while supporting an early Visigothic presence that would gradually occupy the emptiness of power left by the Roman Empire, shows that they took some time to completely replace the vacancy. Those were years of political and social instability when the elites were unsure about their near future and felt the need to constantly reassert their position.

The people living in the Peninsula at that age might have regarded Romans or Visigoths as their ancestors but their culture was neither Roman 
nor Visigothic if compared with the Visigoths who had started the migrations or the people from Imperial Rome. There were no strict Romans or Visigoths but only a sort of third way, born from the mingling and development of two cultures in contact.

Early Medieval Hispania lived in a simultaneous autumn and spring of different ages as old institutions disappeared and others rose in their place. The people, however, surely unaware of what was before and after them, lived in a shared set of beliefs where new and old, Roman and Visigothic, had no contradiction between them, a natural amalgam that is their only possible characterization. 